\title{
MANAJEMEN REDAKSIONAL PORTAL BERITA ONLINE DALAM MENGELOLA MEDIA SOSIAL SEBAGAI SARANA PROMOSI
}

\author{
Moh. Syamsul Arifin \\ Universitas Budi Luhur, Jakarta \\ syam.arifin03@gmail.com ${ }^{1}$
}

\begin{abstract}
ABSTRAK
Media sosial memiliki sifat interaktif yang memungkinkan penggunanya mengonsumsi, membuat konten secara mandiri dan menyebarluaskannya dalam jaringan. Dengan sifat ini, media sosial banyak dimanfaatkan oleh pribadi maupun institusi sebagai sarana promosi. Media online, portal berita Inilah.com, salah satu institusi yang memanfaatkan media sosial untuk mempromosikan konten beritanya kepada publik. Untuk mengetahui bagaimana prosedur kerja Inilah.com dalam manajemen redaksional di ruang redaksi (newsroom) sampai pemanfaatan media sosial (oleh tim teknologi informasi - TI) sebagai sarana promosi yang membutuhkan manajemen komunikasi dua departemen terkait yang berbeda, menjadi tujuan sekaligus objek penelitian ini. Metode deskriptif kualitatif dengan pendekatan studi kasus dalam penelitian ini untuk memberikan gambaran proses sistematis implementasi manajemen redaksional dan komunikasi di Inilah.com. Pola proses di Inilah.com dapat menjadi salah satu acuan bagi media online lainnya dalam mengoperasikan perusahaan portal berita online. Subyek penelitian ini adalah para karyawan di departemen ruang redaksi dimana tim newsroom memproduksi konten dan departemen teknologi informasi dimana tim media sosial mengeksekusi promosi konten. Dengan merujuk pada teoriteori manajemen dapat disimpulkan bahwa Inilah.com telah menerapkan prinsip-prinsip manajemen redaksional dan komunikasi dalam skala sederhana dengan melakukan modifikasi pada level pelaksanaan di lapangan menyesuaikan kondisi efektivitas operasional perusahaan.
\end{abstract}

Kata kunci: manajemen, redaksional, media sosial, promosi, Inilah.com

\begin{abstract}
Social media is interactive allowing the user to consume, create content independently and distribute it in the network. With this trait, social media is utilized by personals or institutions as a means of promotion. Online media portal, Inilah.com, one of the institutions that utilizes social media to promote its news content to the public. To find out how Inilah.com work procedures in the management of redaction in the newsroom until the utilization of social media as a means of promotion that requires communication management of two different related departments, be the goal at the same time the object of this research. Qualitative descriptive method with case studies approach in this research to give description of a systematic process implementation of management redaction and communications at Inilah.com. The pattern process at Inilah.com can be one of references for other online media in running operation of online news portal. The subject of this research is the employees in the editorial (newsroom) where newsroom team produces contents and, information technology department where social media team executes content promotion. By looking at the theories of management, it can be a conclusion that Inilah.com apply the principles of management of redaction and communications in simple scale but modified in execution level to suit the company's condition for effectiveness of the company's operations.
\end{abstract}

Keyword: management, newsroom, social media, promotion, Inilah.com

\footnotetext{
${ }^{1}$ Moh. Syamsul Arifin, S.S, M.Ikom, FIKOM Universitas Budi Luhur, Jl. Ciledug Raya Petukangan Utara, Jakarta Selatan 12260, DKI Jakarta, Email: syam.arifin03@gmail.com
} 


\section{PENDAHULUAN}

Teknologi internet beserta berbagai platform turunannya adalah revolusi bidang teknologi yang berpengaruh besar dalam kehidupan dan budaya manusia. Pengaruhnya masuk kedalam semua sendi kehidupan manusia, tak terkecuali, salah satunya terhadap cara manusia berkomunikasi dan mengakses berita. Berbeda dengan media lama yang bersifat satu arah atau dikenal dengan broadcast, media baru (new media) yang berbasis internet seperti diungkapkan Nicholas Gane dan David Beer (dalam Nasrullah, 2014: 14) memiliki karakteristik network, interactivity, information, interface, archive dan simulation. Dengan sifatsifat ini manusia mampu mengirimkan dan menerima pesan-pesan komunikasi secara mandiri atau dengan kata lain setiap individu di era digital ini bisa mengonsumsi dan membuat konten secara mandiri yang dikenal dengan istilah user-generated content (UGC). Adapun, aktivitas-aktivitas UGC di ruang siber saat ini banyak ditemui pada situs jejaring sosial (social networking site) atau sering disebut dengan media sosial (social media) seperti Facebook (FB), Twitter, Google+, YouTube, Vimeo, Path, dan seterusnya.

Kaplan (2015:197) menyebutkan bahwa media sosial merupakan fenomena unik yang memberikan dampak luar biasa dalam kehidupan bermasyarakat dekade ini, misalnya Barack Obama mempergunakan media sosial sebagai alat kampanyenya untuk berkomunikasi dengan konstituen dan seluruh masyarakat Amerika sehingga media ini menjadi salah satu penentu kemenangannya dalam pemilihan presiden Amerika Serikat yang lalu. Contoh lain, para eksekutif dan konsultan bisnis menggunakan geolocation media sosial sebagai faktorfaktor penting dalam pengambilan keputusan. Di bidang media dan komunikasi Wikipedia yang didirikan 2001 kini menjadi sumber informasi dan rujukan karena memiliki 35 juta artikel dengan 288 bahasa yang berbeda di dalamnya; Facebook yang diluncurkan 2004 telah menghubungkan 1,4 miliar pengguna aktif di seluruh dunia; dan YouTube yang didirikan 2005 merupakan salah satu search engine (mesin pencari) paling mumpuni di dunia maya karena memproses 3 miliar pencarian setiap bulannya.

Penggunaan media sosial semakin meluas dewasa ini bukan hanya digunakan oleh pribadi-pribadi namun juga dimanfaatkan oleh institusi. Umumnya warganet (netizen) menggunakan media sosial untuk hiburan atau berbagi konten pribadi, para jurnalis memanfaatkan media sosial sebagai salah satu sumber informasi dalam pencarian dan produksi berita, dan institusi-institusi seperti perusahaan berita atau portal berita online - istilah lain untuk media online - menggunakan media sosial untuk memublikasikan produk konten beritanya. Seperti diungkapkan oleh Nasrullah (2014:36) bahwa salah satu penggunaan media sosial adalah untuk memublikasikan konten, dan dengan fasilitas grouping yang ada pada media sosial, memungkinkan media online untuk memublikasikan produk konten beritanya kepada audiens (follower-nya) 
dalam jaringan grupnya. Dapat disimpulkan bahwa fungsi promosi berlaku pada kondisi ini, seperti dikemukakan Morissan bahwa promosi terbagi ke dalam dua jenis yaitu promosi konten dan promosi penjualan. Promosi konten mencakup kegiatan untuk menarik serta mempertahankan audiens, sedangkan promosi penjualan ditujukan untuk menarik pemasang iklan (Morissan, 2008: 161).

Media sosial yang dimiliki perusahaan media online, portal berita Www.inilah.com (kemudian disebut Inilah.com - baca: Inilahdotcom) yang dikelola oleh PT Indonesia News Center, meliputi Facebook (FB), Twitter, Google+, dan Vimeo. Penelitian ini fokus pada Facebook (FB) dan Twitter Inilah.com karena Google+ dan Vimeo sudah tidak aktif saat penelitian ini berlangsung. Facebook Inilah.com yang dapat diakses lewat akun@inilahmedia dan Twitter-nya @inilahdotcom merupakan dua aset digital milik portal Inilah.com yang dipergunakan sebagai sarana promosi, untuk penyebaran konten (content spreading/diffusion) untuk tujuan promosi konten. Sebagai sarana promosi konten, akun FB @inilahmedia dan@Twitter@inilahdotcom menyebarkan link-link konten informasi dan berita Inilah.com ke seluruh jaringan anggota yaitu para followernya dalam jaringan di kedua media sosialnya melalui fasilitas sharing (berbagi) dan timeline status, bahkan menyebar secara lebih luas ke sejumlah besar warganet melalui viral (sharing berbalas sharing).
Proses promosi konten dikelola oleh tim media sosial di departemen teknologi informasi (TI), sedangkan produksi konten berita Inilah.com seperti media lain pada umumnya berada dalam kendali tim newsroom di departemen redaksi dengan menjalankan manajemen redaksional. Kedua departemen melakukan komunikasi secara intens dan sistematis agar sirkulasi konten berita mulai dari produksi hingga distribusi ke publik atau pasar berjalan lancar. Proses komunikasi yang dijalankan sangat komplek karena melibatkan banyak personil sumber daya manusia (SDM) di kedua departemen. Noise atau gangguan dalam proses komunikasi sangat mungkin terjadi. Oleh karena itu, sangat menarik untuk meneliti mekanisme komunikasi Inilah.com dalam pelaksanaan manajemen redaksional dan manajemen komunikasi yang menjadi objek penelitian ini. Subyek penelitian ini adalah karyawan Inilah.com di departemen redaksi dan teknologi informasi (TI). Hasil penelitian ini nantinya akan menjadi materi pembelajaran berharga di bidang komunikasi, serta dapat pula menjadi salah satu referensi bagi media online lainnya dalam menjalankan operasional perusahaan portal berita online.

Merujuk teori manajemen media massa Peter Pringle, departemen redaksi Inilah.com secara garis besar menjalankan aktivitas POAC (Planning Organizing, Directing/ Actuating dan Controlling-Evaluating) (Morissan, 2008: 138-167). Manajemen redaksional, manajemen khusus untuk ruang redaksi atau newsroom dirinci 
lagi oleh Fink (dalam Yuniarti, 2009: 29-33) mencakup konsep-konsep Research in the newsroom, Planning in the newsroom, How to manage the newsroom's resources, dan Evaluatingcontrolling in the newsroom.

Berangkat dari prosedur konsep yang dikemukakan Fink, penelitian ini berupaya untuk mengungkapkan mekanisme prosedural yang terjadi di ruang redaksi Inilah.com terkait pelaksanaan manajemen redaksional, serta menggambarkan pola manajemen komunikasi yang berlangsung antara tim newsroom di departemen redaksi dan tim media sosial di departemen TI dalam mengelola media sosial sebagai sarana promosi - studi kasus www.inilah.com.

Setiap perusahaan media online memiliki gaya dan kultur kerja yang unik dalam menjalankan perusahaannya. Begitu juga portal Inilah.com. Media ini digerakkan oleh sumber daya manusia lokal yang tidak begitu besar dari sisi jumlah personil namun tetap profesional dalam menjalankan usaha di bidang jurnalisme. Azas kekeluargaan yang terkandung dalam budaya kerja perusahaan secara tidak langsung berpengaruh pada pola prosedur manajemen operasional perusahaan. Bagaimana implementasi manajemen redaksional di ruang redaksi (newsroom) dalam memproduksi berita, serta bagaimana manajemen komunikasi antara departemen redaksi dan TI dalam mengelola media sosial sebagai sarana promosi merupakan dua pertanyaan yang menjadi rumusan masalah yang akan diungkap dalam penelitian ini. Seberapa luas konsep manajemen Fink diimplementasikan dalam operasional Inilah.com, serta adakah modifikasi konsep-konsep manajemen tersebut menyesuaikan kondisi perusahaan dalam tataran pelaksanaan, akan menjadi gambaran yang menarik untuk dipelajari yang pada akhirnya dapat menjadi pelajaran bermanfaat bagi media online lain dalam mengusahakan efektivitas dalam menjalankan perusahaannya. Dan tentunya, hasil penelitian ini juga akan bermanfaat bagi kalangan akademisi yang berkecimpung dalam bidang ilmu komunikasi sebagai pengayaan keilmuan bidang komunikasi khususnya terkait media online.

\section{METODOLOGI PENELITIAN}

Penelitian ini menggunakan pendekatan kualitatif didasarkan pada tujuan penelitian yang ingin mengungkapkan fenomena atau keadaan apa adanya yang terjadi pada objek penelitian dengan mencari datadata deskriptif tentang kualitas objek yang berupa kata-kata tertulis atau lisan dari orang-orang dan pelaku yang sedang diamati yang terlibat dalam objek penelitian. Dipilihnya pendekatan kualitatif untuk penelitian ini merujuk pada pengertian yang diungkapkan oleh Strauss dan Corbin, dan Libarkin C. Julie (dalam Fitrah, 2017:44) bahwa penelitian kualitatif adalah jenis penelitian yang temuan-temuannya tidak diperoleh melalui prosedur kuantifikasi, perhitungan statistik dan cara-cara lain yang melibatkan ukuran angka-angka, namun menggunakan data 
deskriptif berupa kata-kata tertulis atau lisan dari orang-orang dan pelaku yang diamati. Kualitatif berhubungan dengan aspek makna, nilai dan kualitas yang terdapat di balik fakta, yang hanya bisa diungkapkan dan dijelaskan lewat bahasa, dan kata-kata.

Jenis penelitian yang digunakan adalah deskriptif dan studi kasus. Deskriptif, seperti dijelaskan Sukmadinata (dalam Fitrah, 2017: 36) ditujukan untuk menggambarkan fenomena-fenomena yang ada yang terjadi atau berlangsung saat ini atau masa lampau dengan tidak mengadakan manipulasi atau pengubahan pada variabel-variabel bebas, tetapi menggambarkan kondisi apa adanya. Sedangkan studi kasus adalah untuk eksplorasi mendalam, investigasi kasus pada objek studi yang dibatasi dalam hal waktu, tempat, atau batas-batas fisik yang berupa individu, program, kegiatan, ruang kelas dan kelompok yang diselidiki secara mendalam dengan menggunakan metode pengumpulan data berupa wawancara, observasi lapangan dan dokumentasi (Fitrah, 2017: 37). Merujuk definisi yang dikemukan Pambayun (2013: 247) bahwa alasan digunakan studi kasus dalam penelitian ini untuk lebih memfokuskan penelitian pada satu unit kasus, dengan cara mengungkapkan secara utuh dan lengkap dari kasus tersebut, "menusuk" ke inti permasalahan atau sasaran penelitian hingga mendalam. Metode penelitian deskriptif kualitatif dengan studi kasus yang digunakan dalam penelitian ini untuk menggambarkan, meringkas berbagai kondisi dan situasi untuk kemudian ditarik ke permukaan menjadi ciri, karakter, model dari fenomena realitas dari objek penelitian.

Objek penelitian ini adalah manajemen redaksional media online Inilah.com, mekanisme prosedur kerja di ruang redaksi (newsroom) Inilah.com, dan manajemen komunikasi antara departemen redaksi dan teknologi informasi dalam operasional pengelolaan ruang redaksi dalam produksi konten berita hingga pemanfaatan media sosial sebagai sarana promosi. Subjek penelitian, sebagai informan yang diwawancarai peneliti dalam mengumpulkn informasi dan data, adalah sumber daya manusia (SDM) yang bekerja di kedua departemen tersebut. Dua narasumber sebagai key informan penelitian ini terdiri dari M. Dindien Ridhotulloh (Pemred Inilah.com) dan Gugun Gunadi (Business Development Head \& Social Media Coordinator). Teknik pengumpulan data melalui wawancara atau interview kepada kedua key informan tersebut.

Data dan informasi yang didapat dari hasil wawancara diolah dengan merujuk pada konsep manajemen redaksional Fink dan manajemen komunikasi Robert E. Simmons yang bermuara pada fungsi-fungsi manajemen yang dikemukakan oleh Liebler yang terangkum dalam POAC (planning, organizing, actuating dan controlling).

\section{HASIL DAN PEMBAHASAN}


Implementasi Konsep Manajemen

Redaksional Conrad Fink pada

Ruang Redaksi (Newsroom)

Inilah.com

Konsep manajemen redaksional yang dikemukan oleh Conrad Fink meliputi Research in the newsroom, Planning in the newsroom, How to manage the newsroom's resources dan
Controlling and evaluating the newsroom dengan detil-detil prinsip di setiap konsepnya.

Media online portal berita Inilah.com, secara garis besar, telah mengimplementasikan prinsip-prinsip konsep manajemen redaksional Fink ini yang terangkum dalam tabel berikut.

Tabel 1

Tabulasi Implementasi Konsep Manajemen Redaksional Conrad Fink di Newsroom Inilah.com

\begin{tabular}{|c|c|c|}
\hline \multicolumn{2}{|c|}{ KONSEP } & IMPLEMENTASI \\
\hline $\begin{array}{l}\text { Research In The } \\
\text { Newsroom }\end{array}$ & 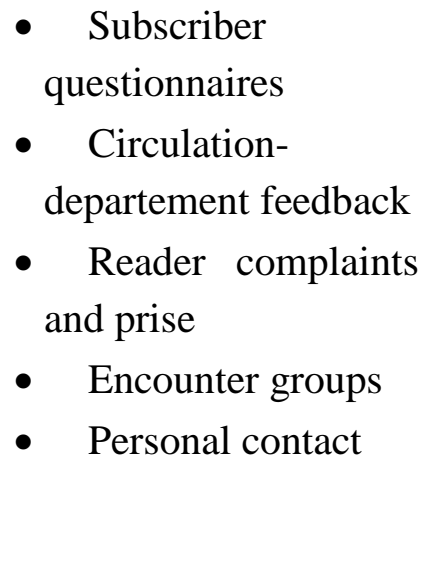 & $\begin{array}{l}\text { - Mengumpulkan database, } \\
\text { feedback masukan dan pujian } \\
\text { (complaint \& praise) dari menu } \\
\text { Citizen Journalism, Suara } \\
\text { Konsumen dan Komentarku. } \\
\text { - Pimpinan berbaur "membumi" } \\
\text { dengan karyawan atau dengan } \\
\text { orang luar misalnya lewat } \\
\text { sarapan bersama sembari diskusi } \\
\text { tentang trending topic. }\end{array}$ \\
\hline $\begin{array}{l}\text { Planning In The } \\
\text { Newsroom }\end{array}$ & $\begin{array}{l}\text { - } \begin{array}{l}\text { Planning effective } \\
\text { use of human }\end{array} \\
\text { resources } \\
\text { - Planning overall } \\
\text { journalistic tone and } \\
\text { the drive for quality } \\
\text { A planning checklist for } \\
\text { quality: } \\
\text { - Make financial } \\
\text { commitment } \\
\text { - Strengthen } \\
\text { newsroom } \\
\text { management } \\
\text { - Strengthen } \\
\text { newsroom staff } \\
\text { Cover the ground }\end{array}$ & $\begin{array}{l}\text { - Rekrutmen dan training } \\
\text { karyawan yang tepat, seperti } 2 \\
\text { reporter khusus saham. } \\
\text { Untuk standar peningkatan } \\
\text { kualitas: } \\
\text { - Gaji karyawan sesuai posisi. } \\
\text { - Pembelian } 20 \text { server baru } \\
\text { untuk menaikkan kinerja portal. } \\
\text { - Rapat rutin tiap setiap hari di } \\
\text { ruang redaksi atau rapat grup } \\
\text { whatsapp. } \\
\text { - Rekrutmen } 20 \text { reporter baru } \\
\text { yang muda dan profesional. } \\
\text { - Sholat lima waktu berjamaah. } \\
\text { - Validasi isi berita sesuai etika }\end{array}$ \\
\hline
\end{tabular}




\begin{tabular}{|c|c|c|}
\hline & $\begin{array}{l}\text { - } \quad \text { Reexamine } \\
\text { coverage strategy } \\
\text { - } \quad \text { Reexamine } \\
\text { newspaper } \\
\text { structure/content } \\
\text { - } \quad \text { Improve/packaging } \\
\text { layout } \\
\text { - Plan for hard news } \\
\text { Plan "Showcase" } \\
\text { improvement } \\
\text { - } \quad \text { Frontpage } \\
\text { - Business section } \\
\text { - } \quad \text { Editorial page } \\
\text { - } \quad \text { Sports section } \\
\text { - } \quad \text { News of record } \\
\text { - } \quad \text { Special sections }\end{array}$ & 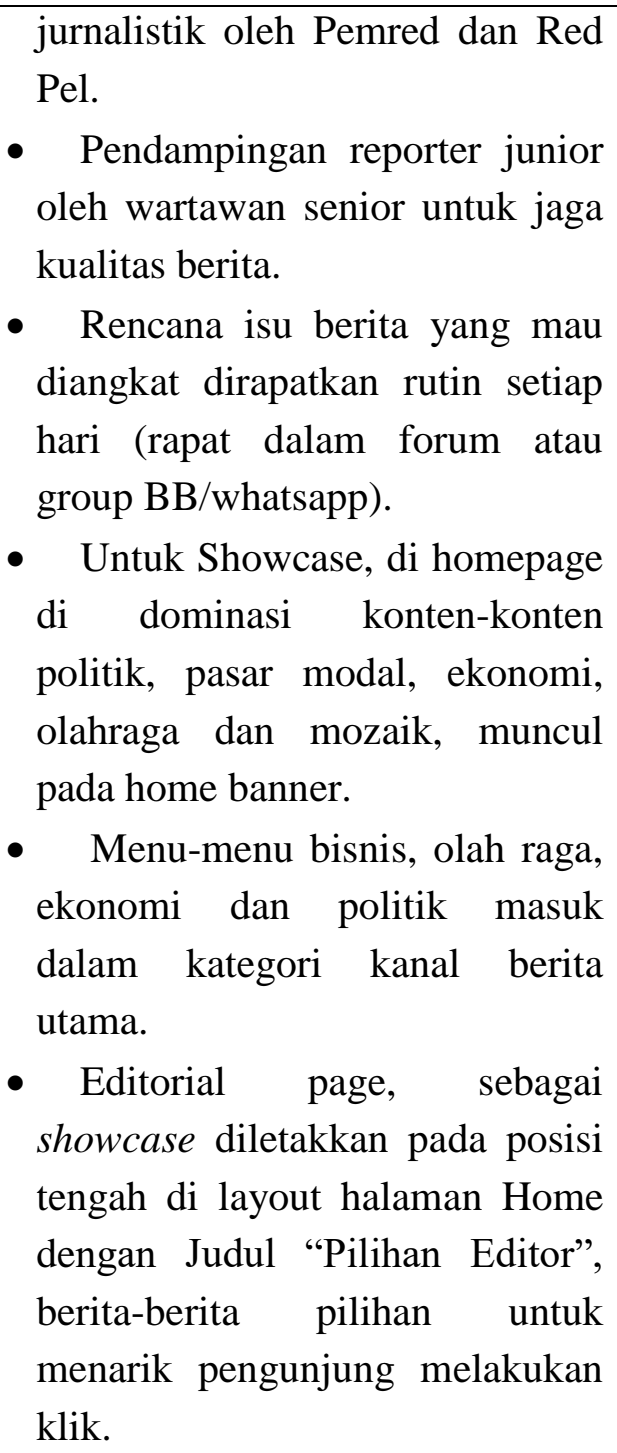 \\
\hline $\begin{array}{c}\text { How To Manage } \\
\text { The Newsroom's } \\
\text { Resources }\end{array}$ & $\begin{array}{ll}\text { - } & \text { Human resources } \\
\text { - } & \text { Money } \\
\text { - } & \text { External resources } \\
\text { - } & \text { Newshole }\end{array}$ & $\begin{array}{l}\text { - A) Rekrutmen karyawan tetap } \\
\text { dan freelance dengan seleksi } \\
\text { ketat untuk posisi yang tepat. B) } \\
\text { Pemberian training sesuai } \\
\text { kebutuhan, seperti } 2 \text { reporter } \\
\text { training kesahaman, juga dapat } \\
\text { dispensasi untuk praktek di lantai } \\
\text { bursa saham. C) Disiplin kerja } \\
\text { dengan } 3 \text { shift jam kerja. D) } \\
\text { Reward bagi reporter yang } \\
\text { konten beritanya paling banyak } \\
\text { diklik dapat uang untuk ngopi di } \\
\text { kafe. E) satu suplier konten } \\
\text { newsroom kantor pusat } \\
\text { Inilah.com Jakarta untuk grup } \\
\text { cross-media Inilahcom Grup - }\end{array}$ \\
\hline
\end{tabular}




\begin{tabular}{|c|c|c|}
\hline & & $\begin{array}{l}\text { prinsip efektif \& efisien. } \\
\text { - } \begin{array}{c}\text { Terkait komitmen money, } \\
\text { perusahaan menggaji }\end{array} \text { secara } \\
\text { proporsional baik untuk } \\
\text { karyawan tetap maupun } \\
\text { freelance. Juga anggaran untuk } \\
\text { operasional perusahaan } \\
\text { ditetapkan secara profesional. } \\
\text { - External resources, membeli } \\
\text { berita dari Kantor Berita Antara; } \\
\text { dan menyewa praktisi untuk } \\
\text { menulis ulasan tertentu yang } \\
\text { bermutu, khususnya rubrik } \\
\text { ekonomi dan pasar modal. } \\
\text { - Newshole, peran editor } \\
\text { dipegang oleh Red Pel (redaktur } \\
\text { pelaksana) yang mengatur } \\
\text { tampilan konten melalui } \\
\text { pembagian } \quad \text { kolom-kolom } \\
\text { halaman portal dengan } \\
\text { mempertimbangkan keunikan dan } \\
\text { kemenarikan judul, bahasa lugas } \\
\text { dan bernilai berita tinggi. Di } \\
\text { homepage dibagi berita-berita } \\
\text { utama pada kolom Banner Utama } \\
\text { dan Pilihan Editor, lalu } \\
\text { dibawahnya berita-berita update } \\
\text { lainnya, lalu Berita Terkini dan } \\
\text { Terpopuler, Highlight News di } \\
\text { sisi kanan. Red Pel melakukan } \\
\text { validasi sebelum berita yang } \\
\text { dikirim reporter ditayangkan ke } \\
\text { portal. }\end{array}$ \\
\hline $\begin{array}{l}\text { Controlling And } \\
\text { Evaluating The } \\
\text { Newsroom }\end{array}$ & $\begin{array}{l}\text { Indikator evaluasi } \\
\text { dalam ruang berita: } \\
\text { - } \quad \text { Kesesuaian produk } \\
\text { dengan kebutuhan dan } \\
\text { keinginan khalayak } \\
\text { - Memenuhi harapan } \\
\text { pemasang pengiklan } \\
\text { - Kesesuaian antara }\end{array}$ & $\begin{array}{l}\text { Mekanisme controlling and } \\
\text { evaluating di Newsroom } \\
\text { Inilah.com yaitu: } \\
\text { a. Rapat rutin pagi dan sore } \\
\text { sebelum jam 16.00. } \\
\text { b. Tim media sosial memberikan } \\
\text { analisa data parametrik } \\
\text { (Google, Facebook dan Twitter } \\
\text { analytic) tentang jumlah orang }\end{array}$ \\
\hline
\end{tabular}




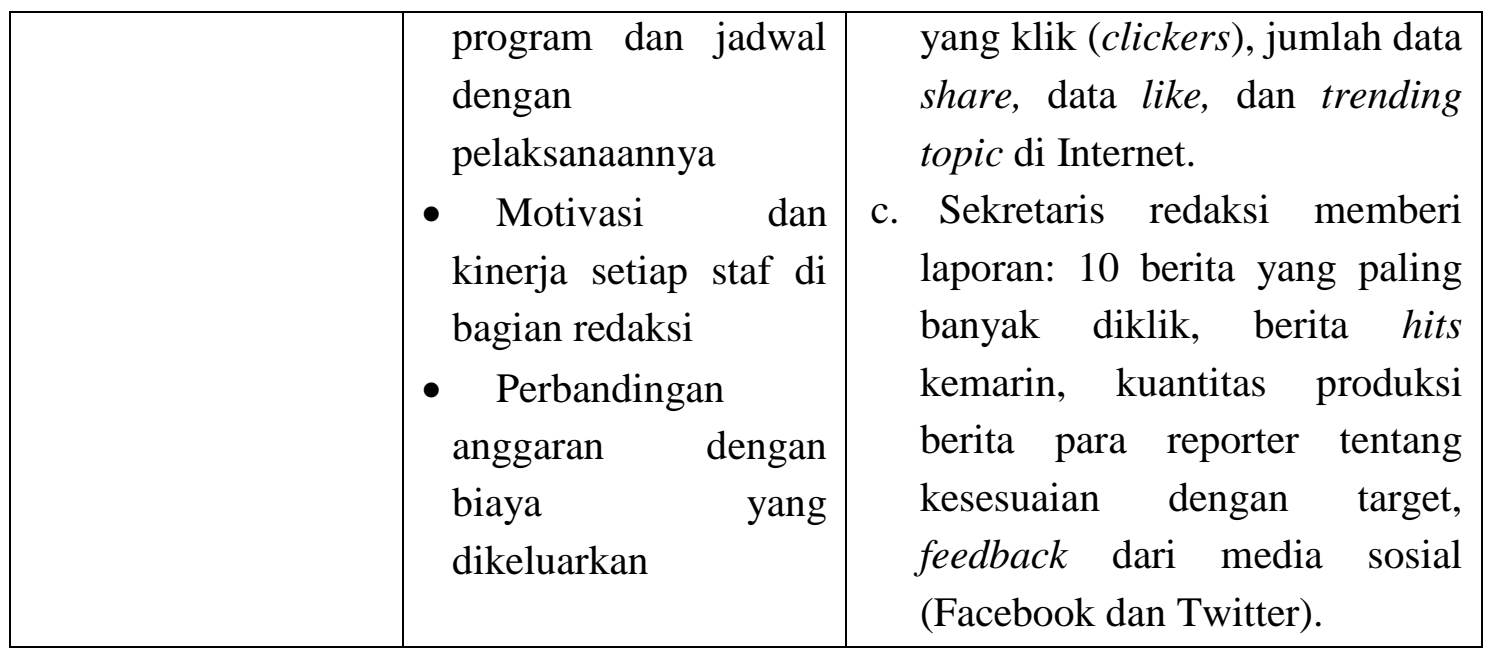

Tabel diatas menjelaskan tentang aktivitas manajemen redaksional yang berjalan di Inilah.com. Pada dasarnya konsep manajemen redaksional yang dikemukan oleh Conrad Fink ini ditujukan untuk media surat kabar sesuai bukunya Strategic Newspaper Management yang dikeluarkan tahun 1996, namun konsep manajemen redaksional Fink ini masih relevan untuk diterapkan bagi media online di era digital ini. Media online tidak berbeda dengan media cetak/surat kabar, hanya wahana internet yang dimiliki oleh media online yang menjadi pembedanya. Oleh karena itu terdapat beberapa konsep yang mengalami modifikasi dalam pengaplikasian manajemen redaksional Fink ini untuk media online, antara lain yaitu: Subscriber questionnaires (mengirimkan kuesioner), Circulation-departement feedback (masukan departemen sirkulasi), Encounter groups (menyelenggarakan grup), Improvel packaging layout (meningkatkan tampilan kemasan) dan News of record (catatan berita) tidak tepat diterapkan di media online.

\section{Sistem Manajemen Komunikasi Antara Ruang Redaksi dan Tim Media Sosial}

Manajemen redaksional pada intinya adalah kegiatan-kegiatan departemen redaksi mulai dari aktivitas riset, rencana produksi konten, penyiapan sumber daya, dukungan finansial, pelaksanaan produksi hingga output berupa produk konten berita/informasi hingga aktivitas kontrol dan evaluasi. Sedangkan pengelolaan media sosial sebagai sarana promosi merupakan aktivitas kerja yang berlangsung di tim media sosial yaitu pemanfaatan aset-aset media sosial Inilah.com untuk tujuan promosi. Pola hubungan komunikasi antara dua departemen ini membentuk sistem manajemen komunikasi tertentu yang diatur sedemikian rupa sehingga setiap anggota pada masing-masing departemen memahami dan mampu melaksanakan tugas tanggung jawabnya masingmasing dengan mengikuti sistem tersebut yang kemudian dibakukan sebagai sistem manajemen komunikasi efektif dan efisien di lingkungan organisasi Inilah.com untuk mencapai tujuan perusahaan.

Dari struktur organisasi Inilah.com Grup jika kita ambil lebih fokus pada kedua departemen yang menjadi objek penelitian akan didapatkan struktur sebagai berikut: 


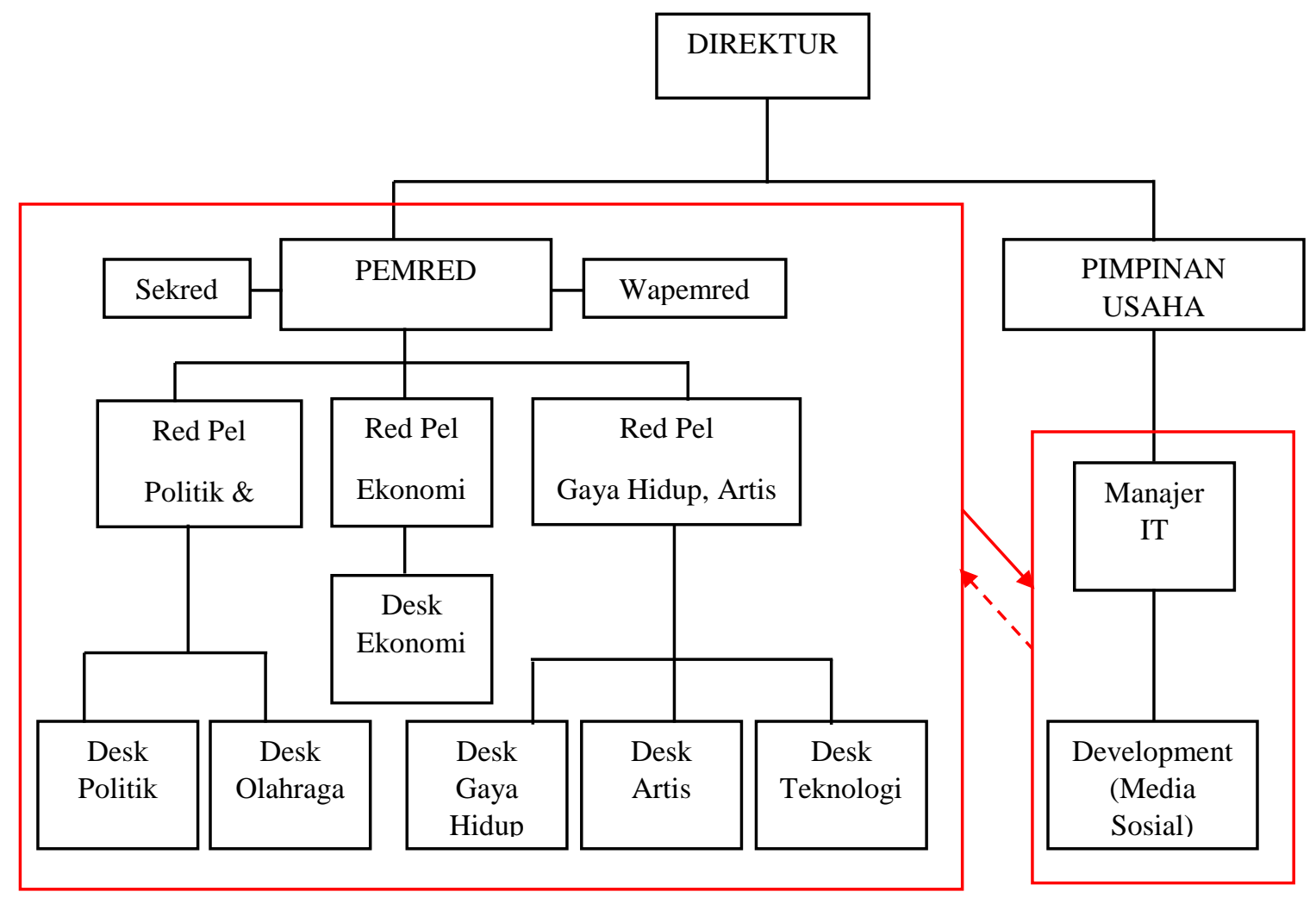

Gambar 1

Struktur Organisasi Dua Departemen (Ruang Redaksi \& Tim Media Sosial) Menjadi Objek Penelitian

(Sumber: Inilah.com)

Keterangan Gambar:

$\longrightarrow$ : Garis penuh untuk perintah langsung

- - - : Garis putus untuk koordinasi/laporan

Bagan diatas menunjukkan tentang dua departemen yang terlibat dalam penelitian ini sebagai objek penelitian, departemen redaksi (ruang redaksi/newsroom) merupakan salah satu departemen paling penting dalam organisasi media termasuk media online, karena dari departemen inilah produk media yang berupa konten berita/informasi diproduksi dan dikeluarkan (release). Sebagaimana model sistem sederhana inputprocess-output (Winardi, dalam
Soedarsono, 2009: 8), maka tahapan process disini terletak di departemen redaksi/newsroom yang mengolah input dengan dukungan semua sumber daya menjadi output hasil produk konten berita/informasi yang siap diunggah ke website portal dan ditarik untuk publish di media sosial Inilah.com.

Output yang merupakan produk konten jadi dari newsroom kemudian dikelola lebih lanjut oleh tim media sosial dibawah koordinasi Gugun Gunadi. Gugun memiliki tugas sebagai 
koordinator Tim Media Sosial Inilah.com sekaligus menjabat sebagai Business Development Head (lihat Gambar 2), sebagaimana diterangkan oleh Pemred Inilah Bapak Dindien:

Bapak Dindien (Narasumber 1): Nah, sekitar 2 tahun terakhir (2014/2015) tim medsos mulai dibentuk lagi, sebuah tim medsos baru yang mungkin tidak sebanyak yang kemarin, tapi tim ini mempunyai strategi-strategi baru (yang nanti detilnya bisa ditanyakan ke koordinator medsos). Tim yang baru ini semuanya karyawan, hanya 1 orang freelance, dan tim dibawahi oleh seorang koordinator sebagai kepala medsos. Koordinator ini bukan hanya mengurusi medsos, tapi dia merangkap memegang posisi lain di Inilah.com - graphic designer, creative campaign, bertugas membuat video grafis, dll juga termasuk mengelola medsos. (wawancara, 8 Juni 2016)

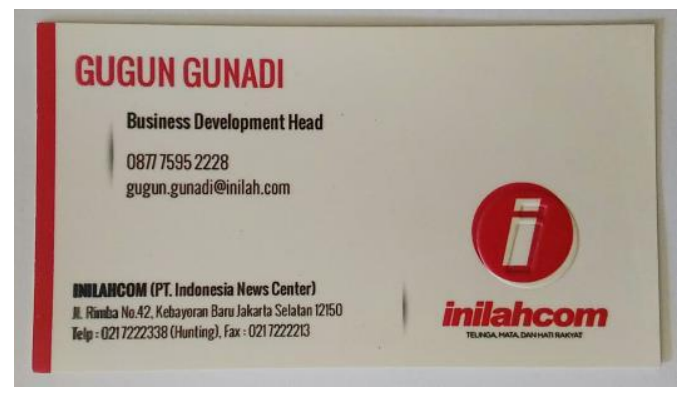

\section{Gambar 2}

\section{Kartu Nama Gugun Gunadi (Narasumber 2)}

Gambar diatas menunjukkan jabatan Gugun Gunadi secara formal di Inilah.com, namun merujuk pernyataan Pemred bahwa Gugun juga merangkap sebagai koordinator medsos. Jika melihat struktur organisasi maka posisi jabatan development disana berada di bawah Manajer IT pada departemen teknologi. Dengan demikian arus komunikasi yang terjadi di Inilah.com terkait manajemen redaksional berlangsung secara diagonal (alur informasi diagonal) yakni ruang redaksi melalui Pemred atau Red Pel (redaktur pelaksana) bisa berkomunikasi secara langsung ke tim media sosial terkait arahan (direction) suatu output konten berita/informasi yang akan dikelola oleh tim media sosial. Hal ini didasari atas pernyataan Pemred:

Bapak Dindien (Narasumber 1): Isu yang kita buat masuk newsroom Inilah.com, masuk ke berita dulu, mereka (tim medsos) menunggu, lalu dari situ diambil dikelola oleh tim medsos. Jadi tim medsos terima konten sudah jadi dan tinggal blast/share kemana-mana. (Wawancara, 13 Juni 2016). 


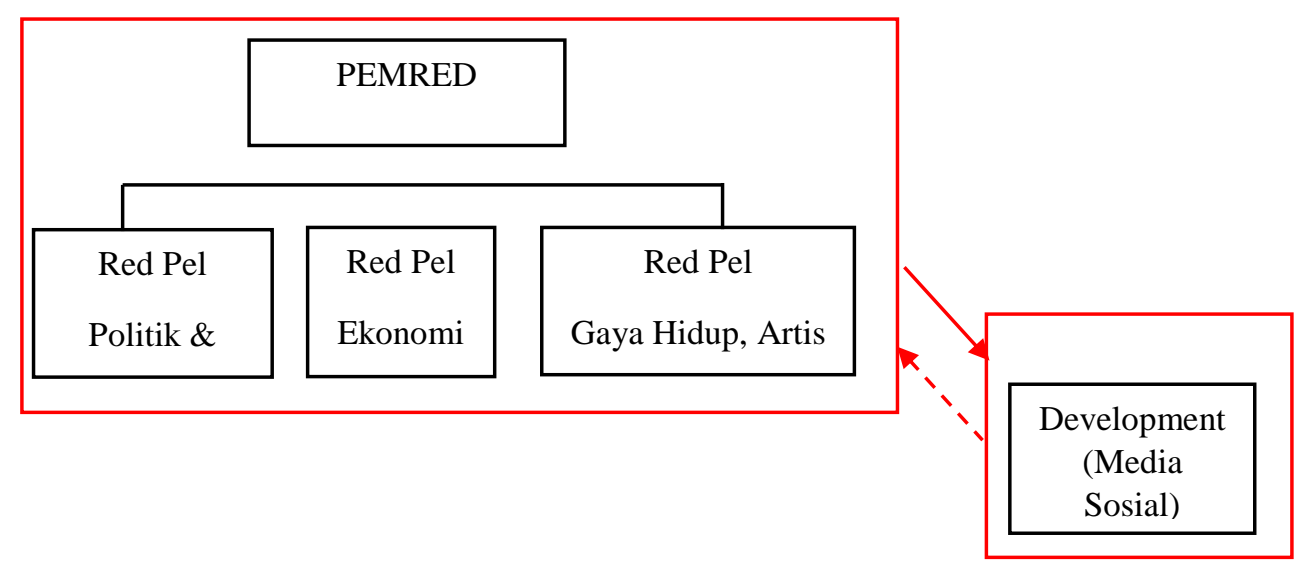

\section{Gambar 3}

\section{Pola Komunikasi Ruang Redaksi dan Tim Media Sosial}

(Sumber: Inilah.com)

\section{Media Sosial Sebagai Sarana Promosi}

Sifat khas media sosial adalah kemudahan dan kecepatan dalam berinteraksi (interactivity) - realtime dan "On" selama 24 jam non stop. Media sosial memiliki khalayak (audiences) yang unik karena mereka adalah prosumer (producer and also consumer) - bisa berperan sebagai produsen informasi sekaligus sebagai konsumen dari informasi tersebut. Media sosial bukan lagi media komunikasi one-to-many tapi berubah menjadi many-to-many. Media sosial bisa menyebar secara masif dalam waktu relatif singkat, dalam hitungan menit bahkan detik.

Inilah.com memiliki empat media sosial, yakni Facebook, Twitter, Vimeo, Google+ sebagaimana tercantum dalam situs portal Inilah.com. Vimeo dan Google+ sudah tidak aktif saat penelitian ini berlangsung, oleh karena itu hanya Facebook (FB) dan Twitter dengan akun FB @inilahmedia dan Twitter-nya @inilahdotcom. Peneliti memerhatikan aliran timeline Facebook dan status Twitter Inilah.com didapatkan gambaran penggunaan media sosial tersebut sebagai promosi.

Merujuk ungkapan Morissan bahwa di media massa promosi terbagi dua, promosi konten dan promosi penjualan. Promosi konten dimaknai dengan penyebaran atau sharing konten di media sosial untuk menarik serta mempertahankan audien (pembaca). Inila.com mengunakan dua aset digitalnya (Facebook dan Twitter) sebagai sarana promosi konten. 


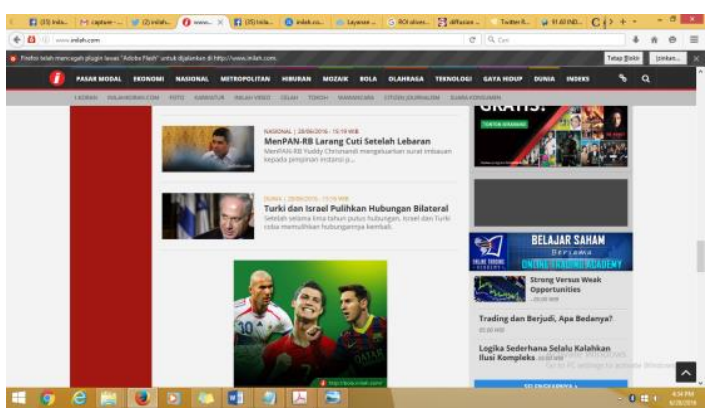

Gambar 4

\section{Headline Website Inilah.com}

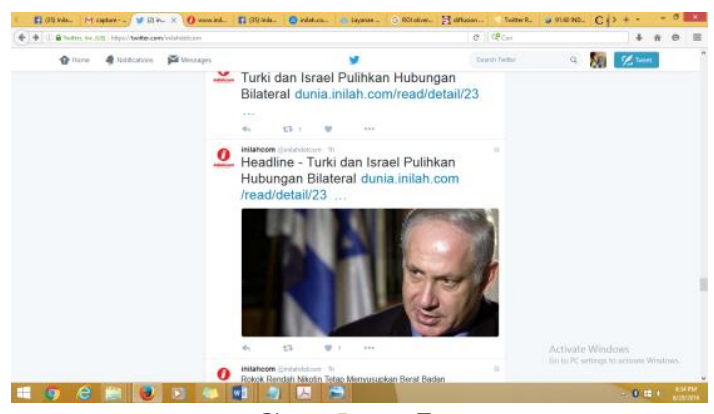

Gambar 5

Timeline Facebook Inilah.com -

Promo Konten Portal Inilah.com

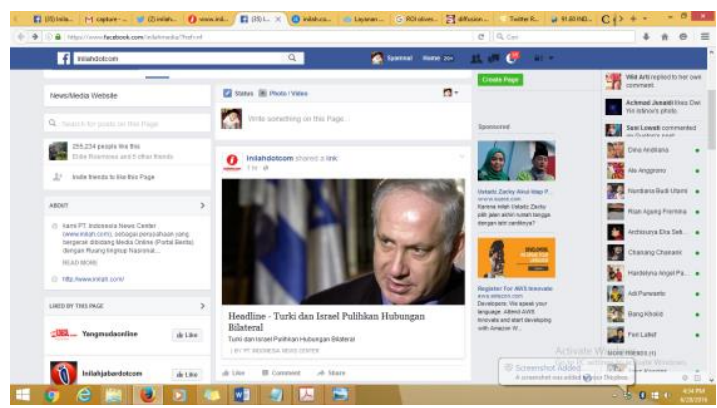

Gambar 6

Timeline Twitter Inilah.com - Promo Konten Portal Inilah.com

Dari ketiga gambar diatas tampak bahwa konten berita "Turki dan Israel pulihkan hubungan bilateral" merupakan sebuah headline di website Inilah.com, yang kemudian dipromosikan lewat media sosial sebagai tawaran produk konten bagi para publik/audiens. Diharapkan dari promosi konten di media sosial media ini akan menarik audiens untuk klik link dan membaca/menkonsumsi konten berita sehingga audiens dapat terpenuhi kebutuhannya mendapatkan berita.

Sebagai promosi penjualan, beberapa berita advertorial dibuat tim newsroom yang dimuat di website, kemudian di promosikan lewat media sosial.

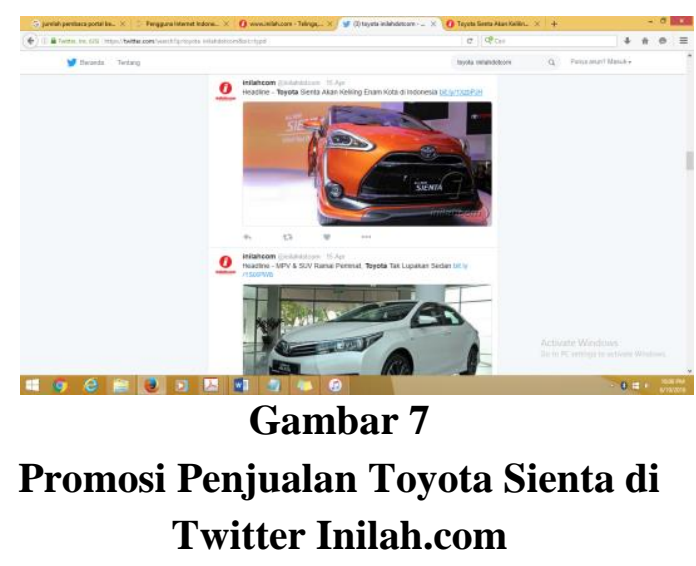

Media sosial Inilah.com, Facebook dan Twitter, berfungsi sebagai sarana promosi konten dan promosi penjualan yang memberikan pengaruh besar bagi revenue atau income perusahaan. Sebagai promosi konten, Facebook dan Twitter menyebar di dunia maya mempromosikan link-link produk konten berita kepada publik dimulai dari grup follower-nya kemudian menyebar pada pengguna-pengguna media sosial lainnya yang tersebar di jagat maya melalui fitur viral sharing. Setiap berita yang diklik oleh pengguna memberikan income bagi Inilah.com. Terlebih lagi, apabila berita mampu memenuhi kebutuhan pengguna atas sebuah informasi, akan membentuk 
loyalty atau kesetiaan menjadi follower Inilah.com sehingga membentuk koloni publik yang berubah fungsi menjadi pasar atau audiens loyal Inilah.com. Audiens ini nantinya dengan jumlah populasi yang semakin besar akan menjadi daya tarik bagi pemasang iklan untuk bertransaksi pemasangan iklan di website Inilah.com seperti iklan advertorial, iklan banner, pop up banner, head banner dan iklan lainnya yang menjadi bagian dari aktivitas promosi penjualan di Inilah.com

\section{SIMPULAN}

Melihat informasi dan data dari hasil wawancara dengan dua narasumber Inilah.com, penulis dapat menarik kesimpulan bahwa Media Online Portal Berita Inilah.com telah mengimplementasikan manajemen redaksional dalam mengelola media sosial sebagai sarana promosi mengacu pada konsep yang dimukakan oleh Conrad Fink dalam bukunya Strategy Newspaper Management yang mencakup empat konsep: Research in the newsroom, Planning in the newsroom, How to manage the newsroom's resources dan Controlling and evaluating the newsroom. Implementasi manajemen redaksional di Inilah.com mengalami modifikasi dalam tataran pelaksanaan lapangan menyesuaikan kondisi perusahaan. Pada Research in the newsroom, pengumpulan database dan feedback melalui jalur menu Citizen Journalism, Suara Konsumen dan komentarku. Pada Planning in the newsroom, Inilah.com lebih fokus pada peningkatan kualitas SDM melalui pemberian training tentang saham untuk dua reporter, dan menambah dua puluh reporter muda profesional untuk dukung semua kanal berita, rapat redaksi rutin setiap pagi dan sore untuk penentuan headline, validasi isi berita oleh Pemred (pimpinan redaksi) dan Red Pel (redaktur pelaksana). Di How to manage the newsroom's resources, Inilah.com membagi jam kerja karyawan kedalam tiga shift, komitmen penggajian karyawan tetap dan freelance secara proporsional, dan membeli berita dari Kantor Berita Antara. Dan yang terakhir, Controlling and evaluating the newsroom, Inilah.com melalukan aktivitas kontrol dan evaluasi melalui rapat rutin untuk evaluasi pekerjaan staf di pagi dan sore hari, analisa data parametrik Facebook dan Twitter dari tim medis sosial untuk angkat isu berita dan pelaporan sekretaris redaksi di setiap sore tentang 10 berita yang paling potensial.

Pola manajemen komunikasi antara departemen redaksi dan teknologi informasi (TI) dalam pengelolaan media sosial sebagai sarana promosi konten bersifat timbal balik dengan arus "perintah langsung" dari Pemred dan/atau RedPel ke tim media sosial. Sedangkan, tim media sosial memiliki wewenang untuk memberikan rekomendari ke tim Newsroom dengan sifat arus "koordinasi".

\section{UCAPAN TERIMAKASIH}

Penulis mengucapkan terimakasih kepada segenap tim media online portal berita Inilah.com, khususnya tim departemen redaksi dan teknologi 
informasi (TI), Pimpinan Redaksi

Inilah.com M. Dindien Ridhotulloh dan Kepala Business Development/ Koordinator Media Sosial Inilah.com Gugun Gunadi atas bantuan dan dukungannya bagi penulis dalam mengumpulkan data dan informasi selama pelaksanaan penelitian.

\section{DAFTAR PUSTAKA}

\section{Buku}

Blanchard, Olivier (2015). Social Media ROI. Mengelola dan Mengukur Penggunaan Media Sosial pada Organisasi Anda. Jakarta. Elex Media Komputindo.

Bungin, Burhan (2007). Penelitian Kualitatif. Komunikasi, Ekonomi, Kebijakan Publik, dan Ilmu Sosial Lainnya. Jakarta. Prenada Media Group.

Bungin, Burhan (2013). Metodologi Penelitian Sosial \& Ekonomi. Jakarta. Kencana Prenada Media Group.

Donsbach, Wolfgang (2015). The Concise Ensyclopedia of Communiction. West Sussex. John Wiley \& Sons, Inc.

Fink, Conrad (1996). Strategy Newspaper Management. Boston. Ally and Bacon.

Fitrah, Muh., M.Pd., dan Dr. Luthfiyah, M.Ag. (2017). Metode Penelitian; Pendidikan Kualitatif, Tindakan Kelas dan Studi Kasus. Jawa Barat. CV Jejak.

Homes, David (2005). Communication Theory: Media, Technology and Society. London, Thousand Oaks. New Delhi. SAGE Publication Littlejohn, Stephen W., dan Karen A. Foss (2009). Teori Komunikasi. Theories of Human Communication. Jakarta. Salemba Humanika.
McQuail, Denis (2011). Teori Komunikasi Massa. McQuail's Mass Communication Theory. Jakarta. Salemba Humanika.

Morissan (2008). Manajemen Media Penyiaran. Strategi Mengelola Radio \& Televisi. Edisi Revisi. Jakarta. Prenada Media Group.

Morissan (2008). Teori Komunikasi Individu Hingga Massa. Jakarta. Prenada Media Group.

Nasrullah, Rulli (2014). Teori dan Riset Media Siber (Cybermedia). Jakarta. Kencana Prenadamedia Group.

Pambayun, Ellys Lestari (2013). One Stop. Qualitative Research Methodology in Communication. Konsep, Panduan dan Aplikasi. Jakarta. Lentera Ilmu Cendikia.

Saifuddin, (2014) Pengelolaan Pembelajaran Teoritis dan Praktis. Yogyakarta. Deepublish Publisher.

Soedarsono, Dewi K. (2009). Sistem Manajemen Komunikasi. Teori, Model dan Aplikasi. Bandung. Simbiosa Rekatama Media.

\section{Jurnal}

Kaplan, Andreas M. (Dec 9, 2015). Social Media, The Digital Revolution and The Business of Media. International Journal on Media Management, 17:197- 199. DOI: 10.1080/14241277.2015.1120014.

Opgenhaffen, Michael dan Leen D'Haenens, (Dec 9, 2015). Managing Social Media Use: Whither Social Media Guidelines in News Organizations. The International Journal on Media Management, 17:201-216. DOI: 10.1080/14241277.2015.1107570.

Carr, Caleb T. \& Rebecca A. Hayes, (Feb 6, 2015). Social Media: Defining, Developing and Divining. Atlantic Journal of Communication, 
23:1, 46-65, DOI:

$10.1080 / 15456870.2015 .972282$
Tesis

Yuniarti, Esthi (2009). Perbandingan

Manajemen Redaksional Situs Berita

Online. Jakarta. Universitas Indonesia. 